\title{
PENGARUH PERENCANAAN PULANG TERHADAP KEPUASAN \\ PASIEN DI RUMAH SAKIT
}

Nur Aini Lubis

\section{Email: nrnlubis@gmail.com}

\section{Latar Belakang}

Keperawatan menurut hasil Lokakarya Nasional keperawatan tahun 1983 adalah suatu bentuk pelayanan keperawatan profesional yang merupakan bagian integral dari pelayanan kesehatan berdasarkan ilmu dan kiat keperawatan berbentuk pelayanan bio psiko sosio spiritual yang konprehensif,ditujukan kepada individu,keluarga dan masyarakat baik sakit maupun sehat yang mencakup seluruh proses kehiupan manusia.

Peran optimal perawat dalam melakukan kepuasan pasien telah berkembang dan mengarah pada tuntutan akan pengetahuan,sikap dan keterampilan yang adekuat untuk mendukung gerakan keselamtan pasien.Sikap merupakan kesiapan atau kesediaan perawat dalam melaksanakan tindakan keperawatan dan bukan merupakan pelaksanaan motif tertentu.Perawat diharapkan mampu bertanggung jawab atas segala sesuatuyang telah dipilihnya dengan segala resiko dan merupakan sikap yang paling tinggi.Salah satu hak pasien yang harus dipenuhi adalah hak memperoleh keamanan dan keselamatan dirinya selama perawatan di rumah sakit ( UU No.44/2009 pada pasal 32 tentang rumah sakit).

Keterampilan sangat dituntut dalam upaya meningkatkan kepuasan pasien karena keterampilan merupakan kemampuan seseorang menerapkan pengetahuan ke dalam bentuk tindakan, keterampilan seseorang pengetahuan ke dalam bentuk tindakan, keterampilan seorang karyawan diperoleh melalui pendidikan dan latihan, menurut Garry Dessler (2005) pelatihan memberikan pegawai baru atau yang ada sekarang keterampilan yang mereka butuhkan untuk melaksanakan pekerjaan.

Discharge planning/ perencanaan pemulangan adalah proses sistematis yang bertujuan menyiapkan pasien meninggalkan rumah sakit untuk melanjutkan program perawatan yang berkelanjutan di rumah atau di unit perawatan komunitas (Taylor,dkk.1989). Program perencanaan pemulangan pada dasarnya merupakan program pemberian pendidikan kesehatan kepada pasien yang meliputi nutrisi,aktifitas/ latihan, obat-obatan dan instruksi khusus yaitu tanda dan gejala penyakit pasien (Potter \& Perry, 2005).

\section{Metode}

Pada pendekatan ini, data diperoleh dengan berbagai cara, antara lain dengan observasi, pembagian angket/kuesioner maupun dengan wawancara langsung, dengan maksud 
mendapatkan data yang dapat dianalisis dengan akurat dan hasil kesimpulannya dapat digeneralisasikan.

\section{Hasil Dan Pembahasan}

Sejalan dengan teori Rosyidi (2013), perencanaan pulang adalah masalah multidisiplin atau interaksi. Ini adalah proses dimana profesional perawatan kesehatan, pasien dan keluarga berkolaborasi untuk memberikan dan mengatur kontinuitas perawatan yang diperlukan pasien. Perencanaan harus berpusat pada masalah pasien, yaitu pencegahan, terapeutik, rehabilitatif dan perawatan yang terus-menerus.

Teori Utama (2003), bahwa kepuasan tidak hanya dipengaruhi oleh faktor dari pihak pemberi pelayanan saja, tetapi juga dipengaruhi faktor dari luar maupun dari dalam diri pasien. Faktor dari dalam mencakup sumber daya, pendidikan, pengetahuan dan sikap. Faktor dari luar mencakup budaya, sosial ekonomi, keluarga dan situasi yang dihadapi. Faktor-faktor dasar yang mempengaruhi kepuasan yaitu;pengetahuan, kesadaran, sikap positif, sosial ekonomi, sistem nilai, pemahaman pasien tentang jenis pelayanan yang akan diterimanya (tingkat pemahaman pasien terhadap tindakan yang diberikan akan mempengaruhi tingkat kepuasan seseorang terhadap tindakan) dan empati yang ditujukan oleh pemberi pelayanan kesehatan, sikap ini akan menyentuh emosi pasien. Faktor - faktor inilah yang akan berpengaruh terhadap kepuasan pasien tentang pelayanan yang diberikan.

Rencanaan pelayanan kesehatan adalah sebuah proses untuk merumuskan masalahmasalah yang berkembang di masyarakat, menentukan kebutuhan dan sumber daya yang tersedia, menuntukan tujuan yang paling pokok, dan menyusun langkah-langkah praktis untuk mencapai tujuan yang telah ditetapkan.

Perencanaan keperawatan adalah bagian dari fase pengorganisasian dalam proses keperawatan sebagai pedoman untuk mengarahkan tindakan keperawatan dalam usaha membantu, meringankan, memecahkan masalah atau untuk memenuhi kebutuhan pasien (Setiadi, 2012).

Program perencanaan pemulangan pada dasarnya merupakan program pemberian pendidikan kesehatan kepada pasien dan keluarganya yang meliputi nutrisi, aktifitas/ latihan, obat-obatan dan instruksi khusus yaitu tanda dan gejala penyakit pasien (Potter \& Perry, 2005). Pendidikan kesehatan persiapan pasien pulang bertujuan untuk memberikan pengetahuan dan ketrampilan yang penting kepada pasien dan keluarganya untuk memenuhi kebutuhan keperawatan berkelanjutan yang akan dilakukan di rumah.

Kepuasan pasien dapat dipicu dengan pemberian pendidikan kesehatan persiapan pasien pulang yang dilakukan oleh perawat sesuai dengan waktu,kebutuhan dan kondisi 
pasien (pemenuhan dimensi keandalan), dan juga dengan menunjukkan sikap bersedia dan segera merespon kebutuhan pasien akan informasi tentang kesehatan (dimensi ketanggapan). Selain itu kemampuan, pengetahuan, kesopanan dan sifat dapat dipercaya yang ditunjukkan oleh perawat pada saat melakukan pelayanan keperawatan bisa meningkatkan kepuasan pasien (dimensi jaminan). Perawat juga menunjukkan sikap penuh perhatian kepada pasien, melayani dengan ramah dan menarik, memahami aspirasi pasien, dan berkomunikasi dengan baik dan benar (dimensi kepedulian). Selaian itu perawat juga menggunakan media dan alat peraga yang tepat dalam memberikan pendidikan kesehatan (dimensi bukti langsung). Oleh sebab itu semua dimensi tersebut harus selalu diperhatikan oleh perawat dalam memberikan pelayanan keperawatan sehingga dapat meningkatkan kepuasan pasien.

Bila perawat dapat bersikap baik dalam memberikan asuhan keperawatan kepada pasien maka dapat dikatakan bahwa perawat tersebut bersikap profesional karena dapat membantu pasien dalam memenuhi kebutuhannya. Dalam suatu layanan kesehatan apabila sikap perawat itu baik maka akan berdampak pada kualitas asuhan yang akhirnya akan mempengaruhi kepuasan pasien.

\section{Penutup}

perencanaan pulang adalah masalah multidisiplin atau interaksi. Ini adalah proses dimana profesional perawatan kesehatan, pasien dan keluarga berkolaborasi untuk memberikan dan mengatur kontinuitas perawatan yang diperlukan pasien. Perencanaan harus berpusat pada masalah pasien, yaitu pencegahan, terapeutik, rehabilitatif dan perawatan yang terus-menerus.

Discharge planning/ perencanaan pemulangan adalah proses sistematis yang bertujuan menyiapkan pasien meninggalkan rumah sakit untuk melanjutkan program perawatan yang berkelanjutan di rumah atau di unit perawatan komunitas (Taylor,dkk.1989). Dalam situasi ini perawat harus mampu memberikan pendidikan sesuai kebutuhan pasien dan juga keluarga pasien yang juga ikut berperan dalam kesembuhan pasien tersebut yang meliputi nutrisi, aktifitas/ latihan, obat-obatan dan instruksi khusus pada saat sedang berada atau menerima asuhan keperawatan dirumah sakit hingga kepulangan pasien tersebut untuk memenuhi kebutuhan kesehatan pasien tersebut dimana perawat memberikan pendidikan dan mampu berikap profesional terhadap pasien untuk mendukung kepuasan pasien. 


\section{Daftar Pustaka}

- Herniyatun,Nurlaila,Sudaryani. 2009. Efektivitas Program Discharge Planning Terhadap Tingkat Kepuasan Pasien Di Rumah Sakit Umum Daerah Kabupaten Kebumen Tahun 2009. Jurnal Ilmiah Kesehatan Keperawatan, Volume 5, No. 3, Oktober 2009.

- Asmadi. (2005). Konsep Dasar Keperawatan. Jakarta : Penerbit Buku Kedokteran EGC

- Budiono. (2016). Konsep Dasar Keperawatan. Jakarta : Kementrian Kesehatan Republik Indonesia

- Sunaryo. (2015). Asuhan Keperawatan Gerontik. Jakarta : CV Andi Offset

- Ariga, Reni Asmara. (2020). Implementasi Manajemen Pelayanan Kesehatan Dalam Keperawatan. Yogyakarta : Deepublish

- Allen, Carol Vastel. (1998). Memahami Proses Keperawatan dengan Pendekatan Latihan. Jakarta : Penerbit Buku Kedokteran EGC

- Elim Layuk,Hasmin Tamsah,Ikhsan Kadir. 2017. Pengaruh Pengetahuan, Sikap Dan Keterampilan Perawat Terhadap Kepuasan Pasien Rawat Inap Di Rs Labuang Baji Makassar. Jurnal Mirai Management Volume 2 No. 2 April - Januari 2017.

- Aminuddin. 2009. Pengaruh Pelaksanaan Perencanaan Pulang Terhadap Kepuasan Pasien. JSK, Volume 3 Nomor 3 Maret Tahun 2009.

- Khamida,Mastiah. 2015. Kinerja Perawat Dalam Memberikan Asuhan Keperawatan Berpengaruh Terhadap Kepuasan Pasien Rawat Inap. Jurnal Ilmiah Kesehatan, Vol. 8, No. 2, Agustus 2015, hal 154-161.

- Elon Kusnadi. 2017. Analisis Kelengkapan Dokumentasi Keperawatan di Ruang Rawat Inap Non Intensive Rumah Sakit X. Jurnal Bidang Ilmu Kesehatan Vol. 9, No. 1, Juni 2017.

- Butar-Butar, J., \& Simamora, R. H. (2016). Hubungan Mutu Pelayanan Keperawatan dengan Tingkat Kepuasan Pasien Rawat Inap di RSUD Pandan Kabupaten Tapanuli Tengah. Jurnal Ners Indonesia, 6(1), 50-63.

- Simamora, R. H. (2005). Hubungan Persepsi Perawat Pelaksana Terhadap Penerapan Fungsi Pengorganisasian Yang Dilakukan Oleh Kepala Ruangan Dengan Kinerjanya Diruang Rawat Inap RSUD Koja Jakarta Utara (Doctoral dissertation, Tesis FIK UI, Tidak dipublikasikan). 